\title{
TP53 Mutation Analysis
}

National Cancer Institute

\section{Source}

National Cancer Institute. TP53 Mutation Analysis. NCI Thesaurus. Code C158957.

A procedure used to detect and identify mutations in the TP53 gene. 